\title{
DINAMIKA PESANTREN NAHDLATUL WATHAN DALAM PERSPEKTIF PENDIDIKAN, SOSIAL, DAN MODAL
}

\author{
Khirjan Nahdi \\ STKIP Hamzanwadi, Jl. Pahlawan No. 70 Pancor Selong, \\ Lombok Timur, Nusa Tenggara Barat, \\ nahdi_nw@yahoo.co.id
}

\begin{abstract}
This article speaks of the dynamics of the Nahdlatul Wathan Pesantren by analyzing its spiritual, social and cultural capitals. The complex nature of the relationship between one capital and another and how this relationship has become the source of the physical and academic development, is in itself an interesting issue to explore. But the Pesantren is not only the product of this relationship. It is also the product of the system that its leaders have built. The paper tries to analyze these dynamics and the changes it has gone through by employing the social, capital and educational theories. To arrive at the objective conclusion, the paper treats the Pesantren as a social system in which triadic relationship between structure, ideology, and culture is found. As a social system, the Pesantren has also to consider the external forces which it is certainly part of. But it is exactly here that the Pesantren - and any social system in that matter-will find itself in a serious dilemma. How the Pesantren will deal with the external forces will be also the issue that the paper is interested to discuss, albeit briefly.
\end{abstract}

Keywords: Pesantren, spiritual capital, socio-cultural capital.

\section{Pendahuluan}

Sejarah pendidikan Indonesia mencatat bahwa pesantren merupakan lembaga pendidikan tertua di Indonesia. Pada perkembangannya, pendidikan ala pesantren tidak semata-mata mengaktualisir pada konteks 'ubûdîah semata, tetapi, lebih jauh dari itu, pendidikan tersebut juga membuat sinergi dengan praktik-praktik mu âmalah. ${ }^{1}$

${ }^{1}$ Martin van Bruinessen, "Konjungtur Sosial Politik di Jagat NU Pasca Khittah 26: Pergulatan NU dekade 90-an", dalam Ellyasa K.H. Dharwis (ed.), Gus Dur, NU, dan Masyarakat Sipil (Yogyakarta: LKiS, 1999), 145. 
Tidak terkecuali eksistensi Pendidikan dalam Pesantren Nahdlatul Wathan. Sebagai sebuah organisasi sosial keagamaan lokal yang bergerak dalam bidang pendidikan, sosial, dan dakwah, Nahdlatul Wathan (selanjutnya disingkat NW) juga menciptakan harmonisasi pendidikan seiiring perkembangan yang terjadi. Beragam persoalan dalam lintas perkembangan Pesantren NW itu muncul baik yang berasal dari pola internal dan eksternal di lembaga tersebut, pergeseran pemikiran dan aksi pendidikan, perubahan bentuk kelembagaan, pengintegrasian nilai-nilai dasar pesantren dengan ideologi modern yang berkembang, kemunculan konflik-konflik pada struktur kepemimpinan, menurunnya tingkat loyalitas santri pada struktur kepemimpinan, pergumulan pesantren dengan setting politik, sosial, dan budaya baik lokal-nasional, perubahan ekspektasi atas investasi modal dan ketidakseimbangan kekuatan antarmodal dalam menjaga eksistensi pesantren, atau bahkan berasal dari ketidakseimbangan bentuk, sisi, dan sumber dinamika antara masing-masing aspek dalam konteks pesantren.

Keberadaan modal sosial dan budaya dalam pendidikan dapat dipahami melalui tiga perspektif teori. Pertama, teori pendidikan yang memandang pendidikan sebagai proses yang menyatu dengan kehidupan manusia dan dalam jangka waktu tertentu tampak melalui pertumbuhan dan perkembangan jiwa, watak, dan kemampuan fisik individu. ${ }^{2}$ Pandangan ini akan melahirkan ide, makna, asas, fungsi, dan tujuan pendidikan, berikut implementasinya. Inti teori ini adalah pola relasional antara pemikiran pendidikan dan aksi pendidikan. ${ }^{3}$ Kedua, teori tentang pendidikan pesantren sebagai sistem (secara internal) yang menyangkut sejarah, kultur, tradisi, dan perkembangan pesantren. Dua pandangan tentang sejarah pesantren, yakni artefak peradaban asli Indonesia yang lahir pada masa pra-Islam dan masa Hindu-Budha. ${ }^{4}$ Pandangan lain mengatakan pesantren merupakan hasil dari proses pencarian ilmu agama Islam di Jazirah Arab, terutama Makkah. ${ }^{5}$ Ketiga, teori tentang dinamika sosial yang membutuhkan keberadaan berbagai modal (spiritual dan sosio-kultural). Pesantren

2 John Dewey, Democracy and Education: an Introduction to the Philosophie of Education (New York: MacMillan, 1964), 977.

3 George F. Kneller, "Philosophy and Education", dalam George F. Kneller (ed.), Foundations of Education (New York: John Wiley and Sons. Inc, 1967), 63.

${ }^{4}$ Nurcholis Madjid, Bilik-bilik Pesantren: Sebuah Potret Perjalanan (Jakarta: Paramadina, 1997), 10.

${ }^{5}$ Bruinessen, "Konjungtur Sosial Politik", 21. 
merupakan organisasi dalam sistem sosial yang mempunyai relasi dengan sistem lain di luarnya, di mana relasi dimaksud akan berdampak pada eksistensinya. Eksistensi pesantren dalam relasi itu akan dipengaruhi oleh sejumlah modal yang dikelola dan dimaknai dalam dinamika yang terjadi. ${ }^{6}$ Modal spiritual dipahami sebagai dasar komitmen individual dan kelompok yang selalu bertanya, untuk apa, mengapa, dan ke mana tujuan hidupnya. ${ }^{7}$ Pemahaman tentang modal sosial dan modal budaya, sebagaimana dikemukakan Pierre Bourdieu, adalah bahwa transaksi dalam struktur dan fungsi sosial tidak hanya membutuhkan sejumlah modal ekonomi sebagai teori-teori ekonomi, tetapi juga modal sosial dan budaya. ${ }^{8}$ Modal sosial sebagai keseluruhan aspek sosial memungkinkan setiap orang melakukan sesuatu dalam struktur sosial, termasuk dalam struktur sosial pesantren.' Unsur penting modal sosial mengandung dimensi tanggung jawab atas kewajiban, harapan, dan kepercayaan terhadap persoalan-persoalam dalam struktur sosial, sebagaimana juga dalam struktur sosial pesantren. Sementara modal budaya dipahami melalui pemahaman atas makna budaya sebagai sistem nilai kolektif dalam struktur sosial. ${ }^{10}$ Karena itu, modal budaya dipahami sebagai sejumlah nilai luhur yang mendasari tindakan bersama untuk tujuan bersama, termasuk nilainilai luhur dalam struktur sosial pesantren.

\section{Sejarah Singkat Pesantren Nahdlatul Wathan}

Nahdlatul Wathan, yang berarti "Kebangkitan Tanah Air (Bangsa)", adalah organisasi sosial keagamaan yang didirikan oleh T.G. Muhammad Zainuddin Abdul Majid (selanjutnya disingkat Hamzanwadi) pada 25 Agustus 1937. Organisasi bergerak dalam beberapa bidang, utamanya dalam bidang sosial, pendidikan, dan dakwah. Tujuan didirikannya organisasi tersebut agar bangsa Indonesia khususnya daerah Nusa Tenggara Barat bangkit dari segala kekurangan dan keterbelakangan. Di situlah kemudian orginasasi

\footnotetext{
${ }^{6}$ Manfred Ziemek, Pesantren dalam Perubahan Sosial, terj. Butche B. Soedjojo (Jakarta: P3M, 1986), 99.

${ }^{7}$ Danah Zohar dan Ian Marshal, Spiritual Capital: Memberdayakan SQ di Dunia Bisnis, terj. Hermawan Kartajaya (Jakarta: Mizan, 2005), 63.

8 Pierre Bourdieu, Practical Reason: On the Theory of Action (Stanford California: Stanford University Press, 1998), 18.

9 James Coleman, The Foundation of Social Theory (Cambridge: Belknap Press of Harvard University Press, 1990), 368-393.

${ }^{10}$ Geert Hofstede dan Gert J. Hofstede, Cultures and Organizations: Software of the Mind (New York: McGrow-Hill, 2005), 191.
} 
tersebut berkembang sampai didirikan madrasah modern yang dinamai Nahdlatul Wathan Diniyah Islamiyah (NWDI) ${ }^{11}$ dan Nahdlatul Banat Diniyah Islamiyah, disingkat NBDI, sehingga nama Nahdlatul Wathan sebagai organisasi diambil dari dua kata pertama nama NWDI tersebut.

Upaya T.G. Hamzanwadi untuk memodernisir lembaga pendidikan Islam dipengaruhi langsung dari Makkah, sepulangnya menimba ilmu di Madrasah al-Șawlatîyah-Makkah. Selain ingin memperbarui sistem pendidikan Islam, sekolah umum yang dikenal sebagai pendidikan Barat dipandang T.G. Hamzanwadi tidak ideal untuk diterapkan di lembaga pendidikan Islam. Sebab keberadaannya disediakan oleh penjajah dengan misi tertentu yang tidak sejalan dengan nilai-nilai Islam. ${ }^{12}$ Oleh karenanya, T.G. Hamzanwadi kemudian memadukan sistem pendidikan klasikal dan modern dalam pendidikan yang dikonsepsikannya.

Perjuangan untuk memperbarui dalam sistem pendidikan Islam tersebut diselimuti oleh pengalaman heroik. Ia harus berhadapan dengan para ulama tradisional yang telah lama eksis di tengah masyarakat. Meski demikian Zainuddin tetap beranggapan bahwa hidup adalah perjuangan, sedangkan perjuangan adalah kelelahan, kesibukan, dan keyakinan. Salah satu semboyannya, "hidup tanpa aqidah dan gagasan tanpa keberanian berkurban adalah sia-sia, hampa, bahkan sesat dan binasa. ${ }^{13}$ Itulah kemudian dia menganggap ideidenya yang awalnya kurang bisa diterima ia anggap sebagai sebuah dinamika kehidupan.

Perkembangan pendidikan di lingkungan Nahdlatul Wathan ditandai dengan dibentuknya institusi tersebut menjadi organisasi sosial keagamaan untuk mempertegas misinya yang bergerak di bidang pendidikan, sosial, dan dakwah. Selain didorong oleh misi tersebut, menurut Fauzan Fuad, pembentukan Nahdlatul Wathan sebagai organisasi juga tidak lepas dari faktor politik. Hal itu terjadi semenjak Nahdlatul Ulama (NU) keluar dari Partai Masyumi untuk membentuk

11 NWDI adalah lembaga pendidikan yang diperuntukkan untuk laki-laki dan diresmikan berdirinya di Pancor, Lombok Timur oleh TGH. M. Zainuddin AM pada tanggal 22 Agustus 1937 dengan dukungan oleh beberapa tuan guru dan dibantu oleh masyarakat sekitarnya.

12 Masnun, et al., Tuan Guru KH. Muhammad Zainuddin Abdul Majid (Jakarta: Pustaka al-Miqdad, 2007), 50.

${ }_{13}$ Nu'man, et al., Biografi Maulana Syeikh TGH. Mubammad Zainuddin Abdul Majid (Pancor: Pengurus Besar Nahdhatul Wathan, 1999), 24. 
partai sendiri, yaitu Partai Nahdlatul Ulama pada tahun 1952.. Sementara T.G. Hamzanwadi yang sejak tahun 1950 sudah diangkat menjadi konsulat organisasi tersebut untuk wilayah Sunda Kecil (Wilayah Bali, NTB, dan NTT) tetap memilih Masyumi sebagai wadah untuk menyalurkan aspirasi politiknya. Langkah dan strategi ini diambil seiring dengan konstelasi politik pada zaman liberal saat itu, sehingga PNI sebagai saingan politik tidak berdaya mengambil kursi pemerintahan di wilayah NTB, maka T.G. Hamzanwadi dipilih menjadi ketua Badan Penasehat Partai Masyumi Daerah Nusa Tenggara Barat pada tahun 1952. ${ }^{15}$

Pada tahun 1953-1955 T.G. Hamzanwadi memfatwakan bahwa organisasi Nahdlatul Wathan menganut kebijakan "Politik bebas". Artinya, organisasi ini tidak berafiliasi dengan kekuatan partai poltik manapun, sehingga ia merestui terbentuknya Partai Nahdlatul Ulama, Persatuan Tarbiyah (PERTI), dan Partai Syariat Islam Indonesia (PSII) di Lombok pada 1953 dan 1954. Namun pada tahun 1955, dengan menimbang "untung-ruginya" dalam berpartai, ia dan organisasinya, Nahdlatul Wathan memilih berafiliasi anggota konstituante periode 1955-1959 hasil dari pemilihan umum pertama pada tahun $1955 .^{16}$

Keikutsertaan Nahdlatul Wathan dalam berpartai dan berpolitik kelihatannya tidak bermaksud untuk menceburkan diri ke dalam dunia itu secara utuh, tetapi justru agar apa yang menjadi program organisasi tersebut dalam membangun masyarakat melalui pendidikan, kegiatan sosial, dan dakwah dapat berjalan sesuai yang diharapakan.

\section{Relasi Internal Pesantren Nahdlatul Wathan}

Pesantren Nahdlatul Wathan (NW) lahir ketika masyarakat masih dalam pengaruh dan tekanan rezim kolonial Belanda. Ciri-ciri umum pendidikan yang ditawarkan oleh pemerintah kolonial Belanda adalah netralitasnya terhadap sikap beragama, berpusat pada peningkatan upaya meningkatkan taraf kehidupan manusia, bukan harmoni, bertujuan mempertahankan sistem kelas dalam masyarakat, dan pembentukan elit baru dalam masyarakat untuk memperkuat struktur

14 Abdul Kabir, "Karakteristik Gerakan Pembaharuan dan Pemikiran TGKH Hamzanwadi”, Jurnal Fikrah, No. 1, Vol. 1 (Juli-Desember 2006), 78.

15 Abdurrahman Wahid, Kiai Nyentrik Membela Pemerintah (Yogyakarta: LKiS, 2000), 133.

16 Muhammad Noor, et al., Refleksi Pemikiran dan Perjuangan Tuan Guru Kyai Haji Muhammad Zaenuddin Abdul Majid (Jakarta: PT. Logos Wacana Ilmu, 2004), 136. 
kekuasaan kolonial Belanda. Kelahiran Pesantren NW dimaksudkan untuk memberikan pencerahan melalui pendidikan berbasis agama (Islam), menegasikan ketimpangan sosial, dan menciptakan sikap egaliter di antara masyarakat. ${ }^{17}$ Kehadiran Pesantren NW diharapkan sebagai fasilitator untuk hajatan itu. ${ }^{18}$

Dinamika yang dialami pada struktur pendidikan pada lembaga pendidikan Pesantren NW bersifat gradual dan simultan. Pola gradual dapat dipahami melalui keberadaan lembaga pendidikan, mulai dari tingkat persiapan selama 1 tahun, 3 tahun, hingga 4 tahun. Demikian pula dengan didirikannya Mu'allimin dan Mu'allimat setingkat Tsanawiyah dan Aliyah, hingga Pondok Pesantren. Pola ini mengandung makna penjenjangan secara kelembagaan. Masingmasing lulusan memiliki peluang untuk melanjutkan pendidikan pada jenjang yang lebih tinggi. Pola simultan tampak melalui pola pengembangan kurikulum dan mata pelajaran. Kurikulum dan mata pelajaran yang dikembangkan bertingkat pada jenjang kelas dan jenjang pendidikan (lembaga). Masing-masing merupakan kelanjutan atau kesinambungan dari kurikulum dan mata pelajaran sebelumnya. ${ }^{19}$

1. Kelembagaan Pesantren Nahdlatul Wathan

Dinamika kelembagaan Pesantren NW dalam analisis ini dipahami dari taksonomi, komponen waktu, wilayah persebaran (ideografik), jenis dan satuan pendidikan, kurun waktu UUSPN (pararelisme), pola dan sumber perubahan, status lulusan, dan akumulasi modal. Untuk kurun waktu 16 tahun (1937-1953), lembaga pendidikan Pesantren NW berkembang menjadi 68 buah madrasah, dan tersebar di seluruh Pulau Lombok; Lombok Timur, Lombok Tengah, dan Lombok Barat. Jadi, rata-rata setiap tahun berdiri empat madrasah pada tempat yang berbeda. Perkembangan dan persebaran madrasah ini terkait dengan dua hal; periode lulusan santri di madrasah induk yang berpusat di Pancor dan di daerah asal lulusan.

Setelah terjadi perubahan organisasi madrasah dan masih dengan pola iląâmiyah (1 tahun), tahdîrîyah (3 tahun), dan ibtidâyahah (4 tahun), santri menuntaskan proses pendidikannya rata-rata selama 3-4 tahun. Lama pendidikan santri bertambah dengan dibukanya Madrasah

17 Noor, et al., Visi Kebangsaan Religius: Refleksi Pemikiran dan Perjuangan TGKH M Zainuddin Abdul Madjid 1904-1997 (Jakarta: Logos, 2004), 204-210.

18 Kneller, "Philosophy and Education", 63.

${ }^{19}$ Yusuf, Sejarah Ringkas perguruan NWDI, NBDI, dan NW (Selong-Lombok Timur NTB: Garuda, 1976), 63. 
Mu'allimin dan Madrasah Mu'allimat 6 tahun. Dalam kurun waktu 1937-1953, Pesantren NW melalui Madrasah NWDI, NBDI, Mu'allimin, dan Mu'allimat 6 tahun meluluskan santri sebanyak 4 kali. Persebaran wilayah berdirinya madrasah yang berafiliasi pada Pesantren NW berkaitan langsung dengan daerah asal santri, daerahdaerah tersebut menjadi basis tempat Majelis Ta'lim yang dipimpin langsung oleh T.G. Hamzanwadi. Biasanya, setelah lulus, para santri dipesankan untuk melanjutkan dan menerapkan ilmunya di tengahtengah masyarakat. Karena itu, para santri minimal menjadi pemimpin agama di wilayah masing-masing, selain berikutnya merencanakan pendirian madrasah. ${ }^{20}$

Jenis dan satuan pendidikan pada kurun waktu ini (Fase I: 19371953) relatif seragam, yakni madrasah setingkat Madrasah Ibtida'iyah (MI), baik untuk pria dan wanita, dengan nama bervariasi, tetapi tetap memakai label NW pada bagian belakang namanya, seperti Madrasah al-Falah NW, Madrasah Haqqulyakin NW, dan seterusnya. Penamaan ini dimaksudkan sebagai bukti sejarah dan jaringan para santri, sehingga satu sama lain dapat saling bertukar santri dan ustaz/guru. Keseragaman jenis dan tingkat pendidikan (MI) pada kurun ini terkait juga dengan kapasitas keilmuan santri yang menggagas pendirian madrasah dan kondisi lokal di wilayah masing-masing. Berdasarkan kurikulum yang dikembangkan di madrasah pada Pesantren NW (yang berpusat di Pancor), kapasitas keilmuan (Islam) santri hanya mampu mengajar pada tingkat MI. Selanjutnya, di wilayah masingmasing belum ada sekolah/madrasah sejenis dan setingkat, sehingga pilihan satu-satunya adalah MI. Walaupun tampak seragam dalam hal kelembagaan, perkembangan Pesantren NW dalam bentuk madrasahmadrasah dapat dimaknai sebagai proses kesejajaran dengan dinamika masyarakat, terutama menyangkut kebutuhan akan pendidikan. Pada tahap awal, fenomena tersebut menggambarkan dinamika yang positif dalam hal kelembagaan (kuantitas), dengan harapan secara normatif perkembangan kelembagaan tersebut dapat memenuhi standar mobilitas vertikal ( habl min Allâh) dan mobilitas horizontal ( habl min al-nâs). ${ }^{21}$

Dinamika berikutnya, dalam kurun waktu 1965-1973, 1973-1975 (Fase II dan III, selama 10 tahun), lembaga pendidikan Pesantren NW berkembang menjadi 360 buah madrasah. Selanjutnya, pada kurun waktu 1982-1986 tercatat 407 madrasah, pada kurun waktu 1986-1994

${ }^{20}$ Ibid., 66.

${ }^{21}$ M. Dawam Rahardjo, Pesantren dan Pembaharuan (Jakarta: LP3ES, 1985), 8. 
(Fase IV) tercatat 675 madrasah, dan pada kurun waktu 1995-2000 (Fase V) tercatat 565 madrasah (pada fase $\mathrm{V}$ ini terjadi penurunan akibat kekurangan santri karena keberhasilan $\mathrm{KB}$, atau berdiri sekolah dasar sebagai implementasi Inpres SD tahun 1974). Satuan pendidikan pada fase II masih sama dengan satuan pendidikan pada fase I, yakni satuan MI, ditambah dengan sejumlah PBA dan pengajian umum yang dikelola secara informal. Kondisi ini disebabkan karena pertimbangan yang sama dengan dinamika kelembagaan pada fase I, yakni kapasitas keilmuan santri yang menggagas berdirinya madrasah. Perkembangan lain terjadi pada fase III, dengan satuan pendidikan yang bervariasi, yakni MI, MTs, dan MA. Perkembangan ini terjadi terkait dengan perkembangan satuan pendidikan di Pesantren NW (induk di Pancor), dengan dibukanya Mu'allimin dan Mu'llimat 6 tahun, dan pada fase ini sudah memiliki lulusan. Para lulusan inilah yang memprakarsai berdirinya madrasah di atas MI. ${ }^{22}$

Pararelisme dengan UUSPN, kelembagaan pendidikan Pesantren NW berada pada dua generasi UUPPSPN, yakni UUSPN No. 19/1965 (fase I hingga III), dan UUSPN No. 2/1989 (fase IV hingga V). Dua hal penting dapat dijelaskan terkait dengan pararelisme ini, yakni pengakuan kelembagaan dan akomodasi kurikulum. Pada UUPPSPN No. 19/1965 sebagai kelanjutan UUSPN No. 4/1950 dan No. 12/1954, kebijakan pemerintah belum berpihak pada pemberdayaan madrasah, dan madrasah belum diakui sebagai bagian dari program pendidikan nasional. Kebijakan pemerintah dalam pemberdayaan madrasah terbatas pada penguatan struktur madrasah semata. Kondisi ini berpengaruh pada kurikulum dan mata pelajaran yang dikembangkan melalui madrasah yang mayoritas didominasi oleh kurikulum dan mata pelajaran keagamaan. Apapun bentuknya, peristiwa ini menjadi sangat penting dalam upaya menguatkan eksistensi pendidikan pesantren, terutama pesantren yang mengelola madrasah dalam sistem pendidikan nasional, walaupun pada tahap ini secara eksplisit posisi pesantren belum terintegrasi menjadi bagian pendidikan nasional. ${ }^{23}$

Generasi kedua, yakni UUSPN No. 2/1989 (fase IV hingga V), yang menegaskan keberadaan madrasah sebagai bagian dari sistem

\footnotetext{
22 Ibid., 11.

23 Masykuri Abdullah, "Pesantren dalam Konteks Pendidikan Nasional dan Pengembangan Masyarakat", dalam Ikhwanuddin Syarif, et al. (ed.), Pendidikan untuk Masyarakat Indonesia Baru: 70 Tahun H.A.R. Tilaar (Jakarta: Grasindo, 2002), 111.
} 
pendidikan nasional. Melalui UUSPN ini, madrasah diakui sebagai sekolah umum yang bercirikan Islam, dan diakui sebagai subsistem pendidikan nasional tahun 1990. Kebijakan ini berimplikasi pada upaya mengakomodir kurikulum nasional dan mata pelajaran lokal (agama) yang dikembangkan di dalam madrasah. Kurikulum madrasah dengan sepenuhnya MI, MTs, dan MA mengacu pada kurikulum 1994 untuk satuan SD, SMP, dan SMU. Akibatnya, kurikulum dan mata pelajaran agama (Islam) yang sebelumnya mendominasi kurikulum dan mata pelajaran madrasah menjadi hanya lima mata pelajaran, antara lain: Qur'ân-Ḥadîth, Fiqh, Aqîdah Akhlâq, Sejarah Kebudayaan Islam, dan Bahasa Arab.

Berdasarkan pembabakan sejarah, kelembagaan Pesantren NW dipetakan dalam tiga babak, yakni fase pendirian dan fase I adalah babak awal (genuine), fase II, III, dan IV adalah babak perubahan (change), dan fase $\mathrm{V}$ hingga saat sampai seterusnya adalah babak pengembangan (development) sebagaimana gambar di bawah ini. ${ }^{24}$

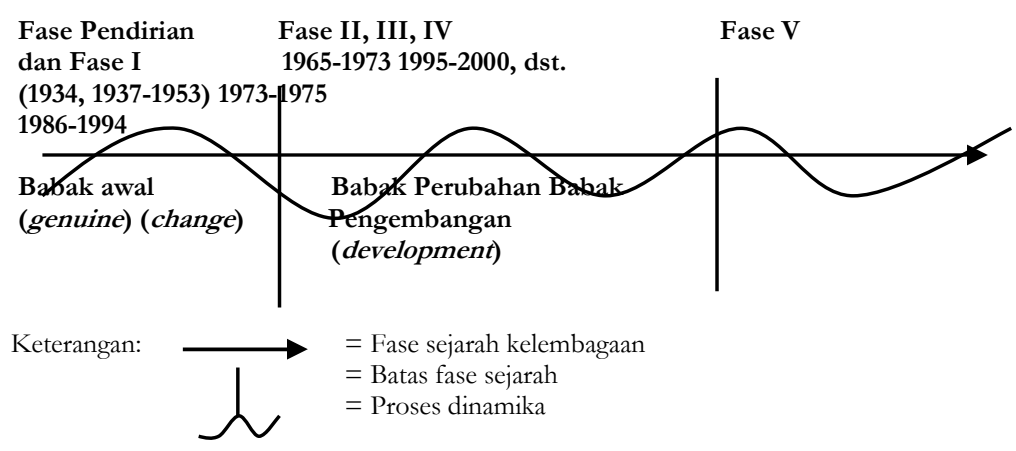

Fase pendirian hingga fase pertama masih merupakan babak sejarah awal karena masih diwarnai oleh keaslian pikiran dan cita-cita awal pendirian Pesantren NW, yang cenderung mementingkan keberadaan struktur, bukan variasinya. Fase II hingga IV masuk babak perubahan karena pada ketiga fase ini Pesantren NW mengalami berbagai perubahan untuk maksud penyesuaian dengan dinamika pendidikan yang terjadi dalam konteks yang lebih luas (nasional). Fase $\mathrm{V}$ masuk babak pengembangan karena Pesantren NW dengan semua komponen strukturnya sudah memiliki bentuk dan pola yang mapan.

24 Agus Salim, Perubahan Sosial: Sketsa Teori dan Refleksi Metodologi Kasus Indonesia (Yogyakarta: Tiara Wacana, 2002), 21. 
2. Pemikiran Pendidikan Nahdlatul Wathan

Domain pemikiran pendidikan yang mendasari aksi pendidikan Pesantren NW dapat dipahami melalui beberapa aspek, antara lain teologis, sosio-kultural, nilai spiritual, fungsional, aspek dialektika transformatif, agen pemikiran, dinamika pemikiran (sumber, agen, pola dinamika), dan akumulasi modal. Ide dasar didirikannya Pesantren NW adalah kesadaran akan tanggung jawab manusia sebagai pemimpin di muka bumi, sebagaimana yang diajarkan dalam agama Islam. Pemikiran ini merupakan hubungan teologi Islam dengan fenomena empirik yang berkembang pada masyarakat Sasak ketika itu. Pemikiran ini muncul karena T.G. Hamzanwadi sebagai agen pemikiran yang memiliki pengetahuan memadai dalam ajaran dan nilai-nilai Islam. Proses ini dipahami sebagai proses idealisasi, yakni kemampuan seseorang melahirkan ide secara bertingkat dalam percaturan idealisme menyangkut Tuhan, alam, dan sesama manusia. ${ }^{25}$ Bagi T.G. Hamzanwadi, sebagai pemimpin di muka bumi, manusia bertanggung jawab secara teologis dan sosial. Untuk dua tanggung jawab tersebut, setiap manusia harus memimpin dirinya dan orang lain yang menjadi tanggung jawabnya. Ada kekhawatiran dalam diri T.G. Hamzanwadi apabila ide-idenya ini tidak dapat diapresiasi oleh sebagian besar masyarakat (Sasak) yang sedang dilingkupi oleh suasana sosio-kultural dan ekonomi yang kurang mendukung. Artinya, tidak semua orang tertindas menyadari ketertindasannya, bahkan kadang-kadang menganggapnya sebagai sesuatu yang taken for granted. Satu hal penting yang perlu dicatat pada diri T.G. Hamzanwadi adalah tanggung jawab sosialnya di mana ide pendirian lembaga pendidikan NW saat itu adalah bagian dari rasa humanitas yang dimilikinya. Rasa yang dimaksud adalah perasaan kasih dan sayang pada masyarakat Sasak dengan kondisi sosio-kultural dan ekonomi yang melingkupinya. ${ }^{26}$

Saat ini sudah terjadi pergeseran paradigma dalam pesantren NW, walaupun pergeseran itu bersifat parsial. Artinya, beberapa hal yang berkaitan dengan pemikiran di atas tidak lagi berjalan sesuai idealisme yang diinisiasikan oleh pendiri awal, T.G. Hamzanwadi. Saat ini sulit

${ }^{25}$ H.A.R. Tilaar dan Riant Nugroho, Kebijakan Pendidikan: Pengantar untuk Memahami Kebijakan Pendidikan dan Kebijakan Pendidikan sebagai Kebijakan Publik (Yogyakarta: Pustaka Pelajar, 2008), 22.

${ }^{20}$ Fuad, Wawancara, Pancor-Selong, 23 September 2009. 
membedakan antara pendidikan sebagai alat dengan pendidikan sebagai tujuan, karena sebagian komunitas Pesantren NW tidak lagi menjadi alat membangun kesadaran untuk perubahan, tetapi bergeser pada pendidikan sebagai instrumen reproduksi sosial dan ekonomi. ${ }^{27}$

3. Kurikulum Pesantren Nahdlatul Wathan

Dinamika kurikulum di Pesantren NW sebetulnya pararel dengan perkembangan pendidikan di Indonesia. Mengingat Pesantren NW adalah lembaga pendidikan yang didirikan untuk membangun kesadaran para anggotanya melalui penegakan nilai dan ajaran Islam, maka kurikulum yang dikembangkan khususnya pada tingkat dasar hingga menengah pada berbagai jenis pendidikan didominasi oleh materi-materi keagamaan (Islam). Fenomena tersebut tampak pada lembaga pendidikan dari fase I hingga III. Pada fase ini, komposisi kurikulum masih 90\% keagamaan dan 10\% umum. Perubahan terjadi sejalan dengan perubahan kurikulum dalam aras pendidikan nasional, penyeragaman kurikulum madrasah, kesejajaran madrasah dengan sekolah formal, dan eksistensi madrasah sebagai subsistem pendidikan nasional (UUSPN No. 2/1989). Sejak penyeragaman kurikulum madrasah tahun 1973, komposisi kurikulum madrasah Pesantren NW bergeser menjadi komposisi 70 keagamaan dan 30\% umum. Kondisi ini sangat dimungkinkan karena rumusan kurikulum madrasah yang ditawarkan sudah mulai dipengaruhi oleh substansi kurikulum 1975.

Sejalan dengan perkembangan kurikulum pendidikan dasar dan menengah, dengan lahirnya kurikulum 1984, komposisi berubah lagi menjadi 55\% keagamaan dan 45\% umum. Puncak dari pergeseran itu adalah ketika lahir kurikulum 1994, di mana seluruh kurikulum dan mata pelajaran madrasah (MI, MTs, dan MA) mengacu pada kurikulum SD, SMP, dan SMU. Kondisi ini merupakan konsekuensi logis dari pengakuan eksistensi madrasah sebagai subsistem pendidikan nasional. Jumlah mata pelajaran, ekuivalensi waktu belajar, dan kurikulum madrasah yang hampir seluruhnya mengacu kurikulum pendidikan umum relatif sama dengan jumlah mata pelajaran dan ekuivalensi waktu belajar ketika kurikulum madrasah belum dipengaruhi oleh kurikulum pendidikan umum. Persoalannya, jika keduanya digabung menjadi satu bagian kurikulum madrasah, akan terjadi pembengkakan menjadi hampir dua kali lipat. Alternatif yang ditempuh para pengelola madrasah ketika itu adalah melakukan simulasi kurikulum untuk mengakomodir kedua kepentingan dalam

${ }^{27}$ Dewey, Democracy, 977. 
konteks ini. ${ }^{28}$ Hasilnya, seluruh kurikulum yang bersumber dari pendidikan umum diakomodir seluruhnya. Untuk kurikulum keagamaan disikapi melalui dua alternatif; beberapa mata pelajaran digabung atau jumlah waktu belajar mata pelajaran tetapnya dikurangi. Sebagai kelanjutan dari penyesuaian tersebut, sejak tahun 1992 madrasahmadrasah di bawah Pesantren NW sudah menjadi bagian yang pembinaannya mengikuti kurikulum nasional dengan menyelenggarakan proses Evaluasi Belajar Tahap Akhir (EBTANAS). Melalui proses penyesuaian tersebut, pesantren tidak cukup hanya menjadi agen tafaqquh fì al-dîn dan islamic value, tetapi juga harus mampu menjadi agen social enginering. Jika tidak, kemungkinan yang terjadi pesantren tidak memiliki peminat karena tidak mampu menyelesaikan masalahmasalah yang sedang berkembang. ${ }^{29}$

4. Habitus dan Lingkungan Pesantren Nahdlatul Wathan

Melintasi batasan sejarah, setelah kemerdekaan diperoleh dan proses pendidikan berlangsung sebagai maksud rekonstruksi peradaban, dalam proses pendidikan perlu dikembangkan pemahaman tentang pentingnya keseimbangan relasi vertikal maupun relasi horizontal. Relasi vertikal perlu dibangun melalui kekuatan-kekuatan spiritual, sedangkan yang kedua memerlukan kecerdasan sosial. Artinya, T.G. Hamzanwadi mengajarkan pentingnya keseimbangan antara keduanya jika bercita-cita menjadi pencipta sejarah dalam perjalanan proses kesejarahannya. Lintasan sejarah berikutnya adalah manusia Sasak yang merdeka, berkesempatan memperoleh pendidikan melalui Pesantren NW, mampu menyeimbangkan kehidupan spiritual dan materialnya, serta berada dalam satu tatanan kenegaraan yang bernama Negara Kesatuan Republik Indonesia. Terkait dengan keberadaan itu, Pesantren NW tidak dapat menghindarkan diri dari akses aturan ketatanegaraan yang berkembang dalam wilayah Negara Kesatuan Republik Indonesia, sebagaimana dipahami melalui tatanan politik negara. Karena memang salah satu pemahaman tentang politik adalah ilmu mengatur dan menguasai negara. ${ }^{30}$ Karena itu, disposisi berikutnya adalah pentingnya afiliasi politik melalui instrumen politik yang ada, sejauh tidak mengganggu keberadaan Pesantren NW.

${ }^{28}$ Sinarep Udin, Wawancara, Pancor-Selong, 12 Mei 2008.

29 Suyata, "Pesantren sebagai Lembaga Sosial yang Hidup", dalam M. Dawam Rahardjo (ed.), Pergulatan Dunia Pesantren: Membangun dari Bawah (Jakarta: LP3ES, 1985), 28.

${ }^{30}$ Miriam Budiardjo, Dasar-dasar Ilmu Politik (Jakarta: Gramedia, 2008), 43. 
Berpolitik bagi T.G. Hamzanwadi adalah menyiapkan instrumen tambahan dan pagar bagi pendidikan Islam melalui Pesantren dan Madrasah NWDI-NBDI.

\section{Relasi Eksternal Pesantren NW}

1. Akomodasi Politik Lokal-Nasional

Terdapat dua pola relasi antara variabel-variabel dalam proses perubahan dan transformasi masyarakat, yakni integrasi atau adaptasi dan konfrontasi. Habitus akan pentingnya pendidikan sebagai instrumen dan tujuan kemerdekaan dari T.G. Hamzanwadi merupakan bentuk perlawanan terhadap kebijakan politik etik kolonial ketika itu, berikut dampak yang ditimbulkannya. Kedua pola relasi ini, dengan memperhatikan catatan sejarahnya tampak dalam dinamika relasi Pesantren NW dengan konteks politik nasional yang dimainkan pada tingkat lokal waktu itu. Pola adaptasi tampak pada ketaatan T.G. Hamzanwadi pada aturan legal formal yang ditetapkan pemerintah kolonial Belanda, seperti izin dan akta pendirian serta kejelasan aktivitas pembelajaran dan kurikulum. Pola konfrontasi tampak pada keterlibatan beberapa kerabat dekat dan santrinya dalam perlawanan fisik terhadap bala tentara kolonial. Bahkan perlawanan tersebut mengakibatkan salah seorang adik T.G. Hamzanwadi meninggal. ${ }^{31}$ Pola relasi antar-variabel dalam konteks ini sebagai relasi agen dan struktur sosial dalam sistem sosial ${ }^{32}$ yang bermuatan konsep, fokus, tujuan, dan atributnya. Konsep terbangun melalui disposisi-disposisi, fokus pada cita-cita transformasi melalui proses pendidikan untuk mencapai kultur sosial yang lebih baik. Khusus menyangkut pendidikan, proses ini disebut sebagai proses dialektika antara konsep pendidikan dan tindakan konkret menyangkut proses dan tujuan pendidikan. ${ }^{33}$ Pada satu sisi kebijakan pendidikan yang demikian memiliki dampak positif terhadap perkembangan Pesantren NW dengan madrasah-madrasahnya, dengan diakuinya sebagai bagian dari sistem pendidikan nasional, terutama melalui UUSPN No. 2/1989 dan UU Sisdiknas No. 20/2003. Dengan diakuinya madrasah dan pesantren dalam sistem pendidikan nasional berarti lulusannya memiliki peluang yang sama dalam setiap kebijakan pemerintah dan

${ }^{31}$ Fauzan, Wawancara, Pancor-Selong, 12 Mei 2008.

32 Anthony Giddens, The Constitutions of Society: Outline of the Theory of Structuration (Berkeley: University of California Press, 1984), 9.

${ }^{33}$ Imam Barnadib, Dasar-dasar Kependidikan: Memahami Makna dan Perspektif Beberapa Teori Pendidikan (Jakarta. Ghalia Indonesia, 1996), 9. 
tata pemerintahan. Secara teknis penyelenggaraan pendidikan, madrasah dapat mengikuti UAN/UN untuk meluluskan para santrinya. Namun demikian, kebijakan demikian secara tidak sadar mengurangi indegeneus pesantren dan madrasah, terutama dalam substansi materi pembelajaran.

\section{Adaptasi Sosio-ekonomi Lokal}

Variabel lain dalam proses transformasi Pesantren NW adalah relasi dengan struktur ekonomi masyarakat lokal di mana Pesantren NW berada (masyarakat Pancor). Situasi keterpurukan dalam berbagai bidang kehidupan akibat kondisi terjajah cukup menggambarkan kondisi ekonomi masyarakat ketika itu. Melalui modal kultural kebutuhan kolektif, dan sikap yang inklusif, Pesantren NW dianggap menjadi milik bersama masyarakat Pancor. Kekuatan modal ini mendorong masyarakat Pancor secara sukarela menyediakan wadah untuk berdirinya madrasah-madrasah melalui tanah wakaf dan sumbangan untuk membangun infrastruktur, seperti bahan bangunan dan sejenisnya. Seiiring bertambahnya kepercayaan masyarakat terhadap Pesantren NW dan semakin dibutuhkannya lembaga pendidikan, maka keberadaan infrastruktur pendukung menjadi semakin penting. Santri-santri lain dari luar Pancor membutuhkan tempat pemondokan karena tidak disediakan oleh pesantren, kebutuhan rumah tangga seperti makanan dan minuman, alat-alat kebersihan, dan lainnya. Demikian juga kebutuhan layanan akademik seperti kios dan toko buku, layanan foto copy dan pencetakan semakin hari semakin dibutuhkan. ${ }^{34}$

Pendidikan dan ekonomi tidak dapat dipisahkan satu sama lain. Idealnya, pendidikan mendukung tujuan-tujuan ekonomi, dan selanjutnya pendidikan membutuhkan pendanaan dari sumber-sumber ekonomi. Di luar persoalan impact ekonomi sebagai akibat positif dan tidak langsung dari keberadaan Pesantren NW, proses sejarah yang panjang, hubungan simbiosis pendidikan dan ekonomi juga dialami oleh Pesantren NW. Ketika fase awal tradisi keislaman cukup kental mewarnai suasana pendidikan di lingkungan pesantren, seperti fungsi transmisi ilmu-ilmu Islam, pemeliharaan tradisi Islam, dan melahirkan ulama, Pesantren NW ternyata berhadapan dengan dinamika sosioekonomi yang membutuhkan fungsi dan produk luar dari pesantren. ${ }^{35}$

34 M. Suruji, Wawancara, Pancor-Selong, 23 Mei 2008.

35 Abuddin Nata (ed.) Sejarah Pertumbuhan dan Perkembangan Lembaga-lembaga Pendidikan Islam di Indonesia (Jakarta: Grasindo, 2001), 112. 
Akibatnya, pada fase III, IV, hingga V sejarah Pesantren NW, ketiga fungsi tersebut sudah mulai berkurang. Transmisi nilai Islam dan pemeliharaan tradisi Islam secara internal masih begitu dominan dalam Pesantren NW. Fenomena tersebut tampak melalui semakin bertambahnya jumlah lembaga pendidikan dan santri pada madrasahmadrasah Pesantren NW.

3. Adaptasi Sosiokultur Lokal

Domain adaptasi sosiokultur lokal dipahami dalam perspektif kelahiran Pesantren NW sebagai lembaga pendidikan. Pesantren NW lahir dalam kancah masyarakat Sasak yang kental dengan pengaruh tradisi Hindu, walaupun sudah berada di bawah rezim kolonial Belanda. Dengan fungsi direktif, yakni melestarikan tata nilai tersebut dan memberikannya sentuhan nilai baru, T.G. Hamzanwadi tidak melakukan purifikasi secara total dalam tradisi tersebut, melainkan diberikan nilai dan tradisi Islam, seperti pemanjatan doa untuk yang sedang berhajat, dan bagi keluarga yang sudah meninggal. Fungsi ini dapat dipahami melalui tradisi rowah-sedekah (dari kata arwah dan sedekah). Acara makan dan minum dalam jumlah besar dan mewah, dialihkan untuk membantu para fakir dan miskin yang membutuhkannya dengan harapan imbalannya kembali kepada yang berhajat, berikut keluarga yang telah meninggal. ${ }^{36}$ Selain fungsi direktif, adaptasi sosio-kultural dilakukan dengan mengedepankan fungsi preservatif, yakni dengan menanamkan nilai untuk kebutuhan masa depan. Bentuk fungsi ini adalah melalui penanaman kesadaran tentang pentingnya kesadaran dan akibat buruk perilaku boros dan bermewah-mewahan. Karenanya, untuk proses tradisi tidak perlu diwarnai dengan sejumlah makanan yang banyak dan berlimpah, sebaiknya diberikan kepada mereka-mereka yang membutuhkan bantuan. ${ }^{37}$ Pemahaman atas fungsi-fungsi tersebut tidak langsung dilakukan sebagaimana struktur pemerintah dalam bentuk instrumen aturan (perda atau SK), atau awig-awig (kesepakatan tidak tertulis), melainkan melalui proses edukatif, seperti pengajian dan pembelajaran madrasah. ${ }^{38}$

Secara sosial, sikap akulturasi sosio-kultural dengan mengedepankan fungsi preservatif dan direktif sangat penting dilakukan mengingat berbagai resistensi atas disposisi T.G.

${ }^{36}$ Dirto Hadisusanto, Pengantar Ilmu Pendidikan (Yogyakarta: IKIK, 1995), 57.

${ }^{37}$ Ibid.

${ }^{38}$ Halidi, Wawancara, Jantuk-Sukamulia, 6 Januari 2010. 
Hamzanwadi. Karena itu semua proses dilakukan secara gradual, mengingat semua tindakannya merupakan habitus yang terjadi dalam kurun sejarah, berproses (processual), dan dinamik. ${ }^{39}$ Selain karena alasan resistensi, keseluruhan atribut pesantren berikut komunitasnya ketika itu menjadi tradisi baru yang minoritas di tengah-tengah tradisi lama yang mayoritas. Saling bersentuhan secara damai di antara keduanya melalui fungsi preservatif dan direktif, tradisi minoritas Pesantren NW hadir untuk memperkuat tradisi mayoritas masyarakat Sasak. Dalam perjalanan sejarah yang panjang, processual, dan dinamik itu, kekuatan modal sosial sangat dibutuhkan. Modal sosial yang berperan dalan relasi ini adalah sikap percaya pada sejumlah diposisi T.G. Hamzanwadi, terutama disposisi yang menyangkut pendidikan dan ajaran Islam.

\section{Pemikiran dan Aksi Pendidikan}

1. Keteladanan

Domain ini dipahami melalui proses dialektika transformatif antara masing-masing variabel dalam disposisi T.G. Hamzanwadi berkaitan dengan konsepnya tentang manusia dan tanggung jawab 'ubûdîyah dan mu'âmalah. Sebagaimana dipahami dalam teologi Islam, manusia adalah pemimpin di muka bumi. Sebagai pemimpin, manusia memiliki tanggung jawab sosial sebagai pemimpin, dan kepemimpinannya mengandung dimensi ibadah. Pemahaman atas tanggung jawab ini menurut T.G. Hamzanwadi membutuhkan proses pendidikan, terutama pendidikan keteladanan, dengan harapan dalam proses yang lama akan menjadi sebuah budaya dalam individu santri. Pemahaman teologis ini sejalan dengan pikiran Ki Hajar Dewantara tentang pentingnya pembumian pendidikan sebagai proses budaya dalam rangka memaksimalkan kodrat individu agar menjadi manusia dan masyarakat yang dipandu dengan tradisi lokal di mana masyarakat itu berkembang. ${ }^{40}$

Bagi T.G. Hamzanwadi, setiap tindakan harus mengandung nuansa ibadah, tanpa dibayang-bayangi oleh motivasi-motivasi keduniaan. Atribut dari konsep dan tujuan tersebut adalah mengajarkan sesuatu dengan terlebih dahulu mencontohkannya. Contoh yang paling konkret adalah ketika beliau menegaskan bahwa semua umat Islam memiliki tanggung jawab ibadah kepada Allah (ḥabl

${ }^{39}$ Giddens, The Constitutions, 2.

40 Ki Hadjar Dewantara, Karya Ki Hadjar Dewantara Bagian Pertama: Pendidikan (Yogyakarta: Majlis Luhur Taman Siswa, 1967), 27. 
min Allâh) di samping juga memiliki tanggung jawab ibadah sosial (ḅabl min al-nâs).

2. Orientasi Keilmuan Santri

Orientasi keilmuan santri di lingkungan Pesantren NW merupakan persoalan sejarah, processual, dan dinamis sebagaimana relasi agen dan struktur. ${ }^{41}$ Pada saat yang sama terjadi relasi triadik antara struktur, kultur, dan aksi. ${ }^{42}$ Sebagai proses sejarah, processual, dan dinamik karena orientasi keilmuan mengalami perubahan dalam kurun sejarah yang berbeda. Ketika fase I, II, hingga III, orientasi keilmuan santri masih mendukung tiga fungsi utama pesantren sebagai agen transmisi nilai Islam, pelanjut tradisi Islam, dan melahirkan ulama. ${ }^{43}$ Orientasi tersebut tampak jelas melalui substansi kurikulum yang didominasi oleh materi keagamaan. Bukti lain adalah kesediaan para santri dan lulusan untuk kembali menjadi penyiar Islam di masyarakat. Namun orientasi tersebut berubah seiring dengan peralihan orientasi ekonomi masyarakat yang sebelumnya mengandalkan hasil pertanian (agraris) menuju ekonomi berbasis industri dan teknologi. Fenomena dimaksud memberikan pengaruh yang signifikan terhadap pendidikan, termasuk pendidikan pesantren. ${ }^{44}$ Pada fase sejarah ini (IV dan V), selain karena kurikulum sudah didominasi oleh kurikulum pendidikan nasional, para santri tidak lagi mempertimbangkan untuk kembali ke masyarakat sebagai penyiar agama, atau melanjutkan pendidikan pada perguruan tinggi Islam, melainkan memilih menjadi birokrat dan teknokrat dengan sebelumnya menempuh pendidikan di perguruan tinggi umum. Berdasarkan pola triadik ini, maka pada fase IV dan V para santri dan lulusan sebagai personal di dalam struktur pendidikan Pesantren NW melakukan aksi dan tindakan sesuai kultur sosio-ekonomi yang melingkupinya. Tindakan yang dilakukan semata-mata untuk maksud kesinambungan hidup, di mana mereka tidak cukup menjalani hidup dengan bekal pemahaman kegamaan semata dalam dunia yang demikian kompleks.

\footnotetext{
41 Pierre Bourdieu, An Introduction to the Work of Pierre Bourdieu: The Practice Theory (London: The Macmillan Press Ltd., 1990), 128.

${ }^{42}$ Ibid., xiv.

${ }^{43}$ Nata, Sejarah Pertumbuhan, 112.

44 Imam Barnadib, Pendidikan, Demokrasi, Otonomi, Civil Society, dan Globalisasi (Yogyakarta: Kanisius, 2000), 10.
} 


\section{Karakteristik Santri}

Domain ini dapat dipahami melalui konsep Ta'lim al-Muta'allim yang ditawarkan al-Zarnujî, bahwa pencari ilmu berniat mencari keridlaan Allah, kebahagiaan akhirat, menghilangkan kebodohan diri dan orang lain, menghidupkan dan menegakkan agama Islam. Keseluruhannya tampak melalui sikap dan perilaku fisik dan non-fisik dalam keseharian santri Pesantren NW. Keteguhan pada nilai Islam tidak saja melalui kegiatan intrakurikuler dengan substansi materi keagamaan, tetapi tampak pada kegiatan di luar kurikuler.

Keseharian santri relatif sederhana dalam hal pakaian yang tidak terkesan mewah. Mereka melakukan segala aktivitas secara kolektif melalui kelompok-kelompok yang terbagi berdasarkan kelas, alamat, dan tempat pemondokan. Mereka juga mandiri dalam kesehariannya di pesantren, seperti memasak dan mencuci sendiri, walaupun masih usia pendidikan dasar. Mereka juga sangat taat pada guru, dengan penghormatan dengan mengucap salam dan mencium tangan, serta bangga memperoleh restu tuan guru untuk satu urusan. Dewey menggambarkan proses pendidikan semacam ini sebagai proses integral antara kesadaran internal individu, kesadaran alamiah, kemanusiaan dan spiritualitas. ${ }^{45}$ Bertolak dari pernyataan Dewey, semuanya menjadi semacam budaya yang berlangsung alamiah, dan modal penggerak semua fenomena yang digambarkan adalah modal spiritual yakin, ikhlas, dan istiqamah.

\section{Akumulasi Modal}

Melalui berbagai tahapan metodologi etnografi dalam kajian ini, dinamika Pesantren NW sebagaimana dideskrispiskan sebelumnya dipandu oleh tiga kekuatan modal (spiritual, sosial, dan kultural) dengan berbagai taksonomi, domain, dan komponennya. Relasi antarketiganya memunculkan berbagai tema budaya yang dapat dimaknai melalui proses dinamika Pesantren NW.

1. Modal Spiritual

Dinamika modal spiritual dalam menopang dinamika Pesantren NW dipahami melalui sumber, unsur pembentuk, posisi, realisasi, dan efek modal spiritual. Dalam perspektif organisasi, termasuk pesantren, modal spiritual lahir dari percaturan kejiwaan dengan kekuatan metafisik yang memiliki konsekuensi transendental dan dimainkan di tingkat horizontal. Sanksi yang ditimbulkannya pun berkaitan dengan

${ }^{45}$ Dewey, Democracy, 69. 
kekuatan metafisik sebagaimana kekuatan metafisik yang diyakini sebagai sumber teologis dari modal ini. Berbeda dengan modal sosial yang lahir dari relasi sosial dan dimanfaatkan untuk kepentingan sosial, sanksi yang timbul pun dalam bentuk sanksi sosial.

Modal spiritual yakin, istiqamah, dan ikhlas bagi Pesantren NW muncul sebagai proses yang hirarkis. Secara teologis, setiap manusia adalah pemimpin yang akan dimintai pertanggunjawaban atas perbuatannya. Dalam konteks ini, T.G. Hamzanwadi merasa berkewajiban untuk mengajarkan berbagai ajaran keislaman sebagaimana yang diketahui dan diyakininya. Warisan ajaran T.G. Hamzanwadi inilah yang kemudian menjadi spirit dari pesantren NW untuk mencapai kehidupan yang lebih baik. ${ }^{46}$

2. Modal Sosial

Analisis modal sosial dalam menopang dinamika sosial terkait dengan pemahaman tentang dinamika interaktif modal sosial aspekaspek internal modal sosial dengan aspek-aspek sosiologis masyarakat yang memanfaatkan aspek-aspek internal tersebut. Domain modal sosial Pesantren NW dalam analisis ini dapat dipahami melalui sumber modal sosial, unsur pembentuk modal sosial, keberadaan atau posisi modal sosial, realitas modal sosial dalam dinamika interaksi, tipologi modal sosial, dan dampak modal sosial. Kehadiran modal sosial Pesantren NW sebagai milik individu dan berikutnya dipahami sebagai milik kolektif dapat diidentifikasi melalui keterkaitannya dengan modal lain, dan sekaligus dapat dipahami sebagai unsur pembentuknya. Bentuk modal percaya pada T.G. Hamzanwadi sebagai salah modal sosial diidentifikasi lahir dari adanya keyakinan pada diri, perilaku, dan setiap disposisi habitual T.G. Hamzanwadi. Diri pribadi, perilaku, dan disposisi habitual T.G. Hamzanwadi diyakini sebagai pintu awal untuk memasuki ranah spiritualitas mencari dan memperoleh keridlaan dan keberkatan. Awalnya, bentuk modal sosial ini lahir secara individual pada diri masing-masing komunitas. Karena rasa percaya (trust) tersebut dihajatkan untuk tujuan bersama melalui Pesantren NW, akhirnya bentuk sosial tersebut menjadi milik kolektif komunitas pesantren. Modal sosial sukarela muncul dari kepercayaan, yang secara spiritual mendorong komunitas untuk melakukan sesuatu secara ikhlas. Sanksi sosial lahir dari sumber norma, sedangkan norma merupakan penjelmaan spiritual istiqamah, karena konsistensi melakukan aktivitas dalam

46 Zohar dan Marshal, Spiritual Capital, 63. 
jaringan sosial harus dipandu dengan adanya norma-norma. Keberadaan modal sosial badan otonom dan organisasi yang disesuaikan merupakan produk modal yang lahir dari konsistensi memperjuangkan dispoisi habitual T.G. Hamzanwadi. Kehadiran modal ini menjadi penopang aktivitas memperjuangkan disposisi dimaksud. Demikian pula dengan keber-adaan potensi informasi yang muncul dari yakin pada setiap pengetahuan penting yang bersumber dari disposisi T.G. Hamzanwadi. Keberadaan modal sosial pentingnya potensi informasi ini bagi komunitas Pesantren NW menjadi kebutuhan secara timbal balik (reciprocity), karena semua komunitas membutuhkannya satu sama lain untuk tujuan yang sama, yakni pemahaman keislaman.

Berdasarkan relasi modal sosial dan modal spiritual dalam bentuk latar bekalang kelahirannya, modal sosial Pesantren NW berasal dari tiga sumber, yakni rasa saling percaya (trust), saling membutuhkan kebaikan (reciprocity), dan pentingnya norma sosial (norm). Jika dipetakan, relasi masing-masing bentuk modal sosial, dengan sumber dan keterkaitannya dengan modal sebelumnya (modal spiritual), adalah bahwa modal muncul dari keikhlasan dari rasa percaya pada tuan guru. Kepercayaan itu merupakan penjelmaan dari bentuk keyakinan. ${ }^{47}$

3. Modal Kultural

Modal kultural memiliki kesamaan dengan modal sosial dalam memandu proses dinamika Pesantren NW mulai fase awal hingga fase pengembangan saat ini. Karena itu, modal kultural juga memiliki sumber, unsur pembentuk, posisi modal kultural bagi komunitas Pesantren NW, realitas modal kultural dalam dinamika interaksi, dan dampak modal kultural. Perbedaan yang signifikan terletak pada konkretisasinya yang sulit diidentifikasi karena tampil dalam bentuk nilai dan ideologi,dan rasa.

Kehadiran semboyan Kompak, Utuh, Bersatu pada awalnya tidak menjadi basis pemikiran Pesantren NW melalui pemahaman makna dan tujuannya. Semboyan ini muncul pada awal fase perubahan ketika terjadi persoalan internal santri terkait kepengurusan pesantren dan organisasi. Semboyan dimaksud diperkuat lagi ketika NW sebagai organisasi kemudian berafiliasi dengan sebuah partai politik tertentu. Kondisi ini sempat membuat gangguan pada internal organisasi dan

47 James Coleman, "Social Capital in the Creation of Human Capital", Journal of Sociology, 94: S95-S120 (1988), 368. 
memberi pengaruh pada keberadaan pesantren. Beberapa fakta menunjukkan bahwa setiap pengurus organisasi NW ketika itu secara otomatis memperoleh restu untuk menjadi calon wakil rakyat (DPRD I dan DPRD II). Tahapan awal untuk memperoleh restu adalah menjadi pengurus organisasi, karena itu posisi pengurus organisasi menjadi penting dan diperebutkan dengan harapan memperoleh restu untuk maju menjadi wakil rakyat. Karena kekisruhan di tingkat internal muncul karena fenomena tersebut, oleh karena itu T.G. Hamzanwadi mengeluarkan semboyan tersebut sebagai pesan moral dalam berjuang melalui Nahdlatul Wathan. ${ }^{48}$

Sebagaimana halnya modal kultural melalui semboyan "Kompak, Utuh, dan Bersatu", kekaguman pada kualitas keilmuan T.G. Hamzanwadi merupakan bentuk penghayatan individual terhadap sosok sang tuan guru. Karena masing-masing memiliki apresiasi yang sama, maka fenomena tersebut menjadi nilai kolektif dalam kurun sejarah yang panjang. Melihat hal itu, maka dapat dibenarkan jika pengetahuan pada kualitas keilmuan seseorang adalah modal budaya bagi pelestarian posisi sosialnya. ${ }^{49}$ Kondisi demikian dialami oleh T.G. Hamzanwadi. Disposisi, ajaran, dan tradisi keilmuannya selalu menjadi acuan proses pendidikan di Pesantren NW. Pada berbagai kesempatan, dirinya seolah-olah ada dan tetap hidup karena selalu menjadi acuan personal jika berkaitan dengan proses pengem-bangan pembelajaran di pesantren.

Akan halnya sikap inklusif Pesantren NW yang muncul, hal itu semata-mata merupakan pertimbangan pribadi T.G. Hamzanwadi. Pikiran yang berkembang adalah bahwa terlalu banyak resistensi pada awal berdirinya pesantren ini. Oleh karenanya, strategi penting yang dikembangkan dalam perkembangan Pesantren NW adalah dengan menciptakan sense of belonging pada masyarakat atas keberadaan pesantren ini. Sejak awal hingga saat ini Pesantren NW tidak dilengkapi dengan salah satu elemen pokok, yakni pondok bagi santri. Para santri tinggal bersama masyarakat di sekitar pondok dan menjadi satu kesatuan dengan masyarakat. Pada awalnya, strategi ini tidak dirasakan oleh sebagian komunitas pesantren. Setelah muncul impact ekonomi dari pola ini, masyarakat menganggapnya menjadi sangat strategis, dan akhirnya jadilah inklusivitas ini sebagai nilai kolektif.

48 Zainuddin Badrun, Wawancara, Dasan Lekong-Sukamulia, 6 Juli 2009.

${ }^{49}$ Kuntowijoyo, Metodologi Sejarah (Yogyakarta: Tiara Wacana, 2003), ix. 


\section{Penutup}

Aspek ideologis dan non-ideologis secara relasional mewarnai dinamika Pesantren NW. Pada fase awal, Pesantren NW lahir sebagai instrumen gerakan pembebasan atas tekanan politik etik rezim kolonial yang diskriminatif di bidang pendidikan. Relasi faktor ideologis dan non-ideologis pada fase perubahan dan pengembangan tampak dalam wujud yang beragam. Pendidikan melalui Pesantren NW menjelma tidak semata-mata menjadi alat pergerakan tanah air, purifikasi Islam, dan tawaran lembaga pendidikan modern dalam bentuk madrasah, tetapi ia menjadi pendidikan sebagai tujuan. Relasi faktor ideologis dan non-ideologis yang berpengaruh pada dinamika Pesantren NW tampak pula pada pola relasional antara pemikiran dan aksi pendidikan. Pikiran melahirkan Pesantren NW sebagai instrumen perubahan peradaban tidak lepas dari substansi gerakan perubahan peradaban itu sendiri, yakni kondisi diskriminatif dan tertekan menuju kemerdekaan dan kesetaraan dalam segala aspek kehidupan dan purifikasi ajaran Islam sebagai bagian dari fungsi pokok pesantren.

Proses dinamika Pesantren NW berpengaruh signifikan terhadap modal dalam bentuk orientasi dan pola relasi antarmodal. Pada fase awal, modal spiritual menjadi menonjol di antara kedua modal lainnya mengingat motivasi dan ekspektasi atas investasi modal masih diwarnai dengan motivasi dan ekspektasi ridâ Allah. Kondisi ini sangat wajar mengingat antar-aspek tidak mempunyai keterikatan yang kuat. Fase berikutnya (perubahan dan pengembangan), keberadaan modal sosial menjadi sangat penting dan tampak signifikan. Berdirinya lembaga pendidikan berbentuk madrasah pada berbagai satuan di berbagai pelosok asal santri menjadi pembuktian peran modal sosial.

Relasi faktor ideologis dan non-ideologis yang tampak melalui pemikiran dan aksi pendidikan menunjukkan adanya dinamika simultan dan gradual pada fase awal dan dinamika parsial pada fase perubahan dan pengembangan dengan sumber dinamika eksternal. Pada ketiga fase itu juga tampak dinamika dalam hal motivasi dan ekspektasi atas investasi keseluruhan modal, yang hanya semata-mata mencari ridâ Allah bertambah untuk maksud yang lebih pragmatis. Fenomena yang penting dalam proses dinamika tersebut adalah peran signifikan dari modal spiritual. Modal spiritual menjadi penting dalam dinamika Pesantren NW mengingat keberadaannya dapat menjadi core capital atau ultimate capital karena dapat menjembatani konsensus ketika terjadi gangguan pada kedua modal lainnya. 


\section{Daftar Rujukan}

Abdullah, Masykuri. "Pesantren dalam Konteks Pendidikan Nasional dan Pengembangan Masyarakat", dalam Ikhwanuddin Syarif, et al. (ed.), Pendidikan untuk Masyarakat Indonesia Baru: 70 Tabun H.A.R. Tilaar. Jakarta: Grasindo, 2002.

Badrun, Zainuddin. Wawancara. Dasan-Sukamulia, 6 Juli 2009.

Barnadib, Imam. Dasar-dasar Kependidikan: Memahami Makna dan Perspektif Beberapa Teori Pendidikan. Jakarta. Ghalia Indonesia, 1996.

-----. Pendidikan, Demokrasi, Otonomi, Civil Society, dan Globalisasi. Yogyakarta: Kanisius, 2000.

Bourdieu, Pierre. An Introduction to the Work of Pierre Bourdieu: The Practice Theory. London: The Macmillan Press Ltd., 1990.

-----. Practical Reason: On the Theory of Action. Stanford California: Stanford University Press, 1998.

Bruinessen, Martin van. "Konjungtur Sosial Politik di Jagat NU Pasca Khittah 26: Pergulatan NU dekade 90-an", dalam Ellyasa K.H. Dharwis (ed.), Gus Dur, NU, dan Masyarakat Sipil. Yogyakarta: LKiS, 1999.

Budiardjo, Miriam. Dasar-dasar Imu Politik. Jakarta: Gramedia, 2008.

Coleman, James. "Social Capital in the Creation of Human Capital", Journal of Sociology, 94: S95-S120, 1988.

-----. The Foundation of Social Theory. Cambridge: Belknap Press of Harvard University Press, 1990.

Dewantara, Ki Hadjar. Karya Ki Hadjar Dewantara Bagian Pertama: Pendidikan. Yogyakarta: Majlis Luhur Taman Siswa, 1977.

Dewey, John. Democracy and Education: an Introduction to the Philosophie of Education. New York: MacMillan, 1964.

Fauzan. Wawancara. Pancor-Selong, 12 Mei 2008.

Fuad. Wawancara. Pancor-Selong, 23 September 2009.

Giddens, Anthony. The Constitutions of Society: Outline of the Theory of Structuration. Berkeley: University of California Press, 1984.

Hadisusanto, Dirto. Pengantar Ilmu Pendidikan. Yogyakarta: IKIK, 1995.

Halidi. Wawancara. Jantuk-Sukamulia, 6 Januari 2010.

Hofstede, Geert dan Hofstede, Gert J. Cultures and Organizations: Software of the Mind. New York: McGrow-Hill, 2005. 
Kabir, Abdul. "Karakteristik Gerakan Pembaharuan dan Pemikiran TGKH Hamzanwadi”, Jumal Fikrah, No. 1, Vol. 1, Edisi 1, JuliDesember 2006.

Kneller, George F. "Philosophy and Education", dalam George F. Kneller (ed.), Foundations of Education. New York: John Wiley and Sons. Inc, 1967.

Kuntowijoyo. Metodologi Sejarah. Yogyakarta: Tiara Wacana, 2003.

Madjid, Nurcholis. Bilik-bilik Pesantren: Sebuah Potret Perjalanan. Jakarta: Paramadina, 1997.

Masnun, et al. Tuan Guru KH. Muhammad Zainuddin Abdul Majid. Jakarta: Pustaka al-Miqdad, 2007.

Nata, Abuddin (ed.). Sejarah Pertumbuhan dan Perkembangan Lembagalembaga Pendidikan Islam di Indonesia. Jakarta: Grasindo, 2001.

Noor, Muhammad, et al. Visi Kebangsaan Religius: Refleksi Pemikiran dan Perjuangan TGKH M Zainuddin Abdul Madjid 1904-1997. Jakarta: Logos, 2004.

-----. Refleksi Pemikiran dan Perjuangan Tuan Guru Kyai Haji Mubammad Zaenuddin Abdul Majid. Jakarta: PT. Logos Wacana Ilmu, 2004.

Nu'man, et al. Biografi Maulana Syeikh TGH. Mubammad Zainuddin Abdul Majid. Pancor: Pengurus Besar Nahdhatul Wathan, 1999.

Rahardjo, M. Dawam. Pesantren dan Pembaharuan. Jakarta: LP3ES, 1985.

Salim, Agus. Perubahan Sosial: Sketsa Teori dan Refleksi Metodologi Kasus Indonesia. Yogyakarta: Tiara Wacana, 2002.

Suruji, M. Wawancara. Pancor-Selong, 23 Mei 2008.

Suyata. "Pesantren sebagai Lembaga Sosial yang Hidup", dalam M. Dawam Rahardjo (ed.), Pergulatan Dunia Pesantren: Membangun dari Bawah. Jakarta: LP3ES, 1985.

Tilaar, H.A.R. dan Nugroho, Riant. Kebijakan Pendidikan: Pengantar untuk Memahami Kebijakan Pendidikan dan Kebijakan Pendidikan sebagai Kebijakan Publik. Yogyakarta: Pustaka Pelajar, 2008.

Udin, Sinarep. Wawancara. Pancor-Selong, 12 Mei 2008.

Wahid, Abdurrahman. Kiai Nyentrik Membela Pemerintah. Yogyakarta: LKiS, 2000.

Yusuf. Sejarah Ringkas Perguruan NWDI, NBDI, dan NW. SelongLombok Timur NTB: Garuda, 1976. 
Ziemek, Manfred. Pesantren dalam Perubahan Sosial, terj. Butche B. Soedjojo. Jakarta: P3M, 1986.

Zohar, Danah dan Marshal, Ian. Spiritual Capital: Memberdayakan SQ di Dunia Bisnis, terj. Hermawan Kartajaya. Jakarta: Mizan, 2005. 